\title{
BMJ Global Health Healthcare of Indigenous Amazonian Peoples in response to COVID-19: marginality, discrimination and revaluation of ancestral knowledge in Ucayali, Peru
}

Doreen Montag (D) , ${ }^{1}$ Marco Barboza, ${ }^{2}$ Lizardo Cauper, ${ }^{3}$ Ivan Brehaut, ${ }^{4}$ Isaac Alva, ${ }^{5}$ Aoife Bennett, ${ }^{6}$ José Sanchez-Choy, ${ }^{7}$ Juan Pablo Sarmiento Barletti, ${ }^{8}$ Pilar Valenzuela, ${ }^{9}$ José Manuyama, ${ }^{10}$ Italo García Murayari, ${ }^{11}$ Miguel Guimaraes Vásquez, ${ }^{12}$ Celso Aguirre Panduro, ${ }^{13}$ Angela Giattino, ${ }^{14}$ Edwin Julio Palomino Cadenas, ${ }^{15}$ Rodrigo Lazo, ${ }^{16}$ Carlos A Delgado, ${ }^{17,18}$ Alfonso Nino, ${ }^{19}$ Elaine C. Flores (D) ,1,20 Maria Amalia Pesantes, ${ }^{21,22}$ Juan Pablo Murillo, ${ }^{23}$ Luisa Elvira Belaunde, ${ }^{24}$ Sergio Recuenco, ${ }^{2}$ Robert Chuquimbalqui, ${ }^{2}$ Carol Zavaleta-Cortijo ${ }^{19}$

To cite: Montag D, Barboza M, Cauper L, et al. Healthcare of Indigenous Amazonian Peoples in response to COVID-19: marginality, discrimination and revaluation of ancestral knowledge in Ucayali, Peru. BMJ Global Health 2021;6:e004479. doi:10.1136/ bmjgh-2020-004479

Handling editor Seye Abimbola

Received 16 November 2020 Accepted 22 November 2020

D) Check for updates

(C) Author(s) (or their employer(s)) 2021. Re-use permitted under CC BY. Published by BMJ.

For numbered affiliations see end of article.

Correspondence to Dr Doreen Montag; d.montag@qmul.ac.uk
Systematic and persistent discrimination against Indigenous Peoples translates into differential health outcomes when analysed through ethnicity and/or mother tongue. ${ }^{1}$ In Peru, morbidity and mortality rates among Indigenous Peoples for COVID-19 appear to confirm this. ${ }^{2}$ The COVID-19 pandemic has highlighted the historical structural violence against Indigenous Peoples that currently takes a disproportionate toll in the Peruvian Amazon. This equally applies to Indigenous Andean Peoples and Afro Peruvians. Indigenous Peoples in voluntary isolation and those in initial contact are at highest health risk in this pandemic as they have no previous immunity against common infectious diseases, and lack access to public healthcare services. The Peruvian government introduced a state of emergency early on, but it did not work as theoretically expected because of the deeply rooted inequalities in Peru.

Public policies focused on reducing health inequities affecting Indigenous Peoples in peri-urban Amazonian contexts are urgently needed. ${ }^{3}$ Essentially, Indigenous Peoples (through their legitimate representatives) ought to be incorporated in the planning, monitoring, implementation and evaluation of those public policies to ensure sustainability, equity and inclusion in the short, medium and long run. It is also urgently necessary to rethink Peru's health system to ensure it has an intercultural approach, designed for and with Indigenous Peoples in terms of prevention, treatment and access during and beyond the pandemic. An intercultural approach to healthcare implies that health services not only respects indigenous medical practices but promotes and enables joint and complementary interactions between biomedical and indigenous medical approaches to prevent and treat healthcare problems. ${ }^{4}$ In the last 15 years, Peru has produced more than 10 official documents on intercultural health, but very little of this has turned into practice. The problem is not the lack of an approach, as such, but the incapacity to turn it into practice.

Transforming the current health system to one where indigenous people have an active role and a direct governance mandate with specific budget allocation would be a step forward to address the current limitations in Peru's health system in relation to providing equal access, prevention and treatment of Indigenous Peoples in urban, peri-urban and rural areas. For this, it is important to comprehend the context in which Indigenous Amazonian Peoples have experienced the pandemic, as we will outline below.

First, the pandemic occurs in an Amazonian context of biodiversity loss, rising deforestation, exposure to pollutants and forest fragmentation. ${ }^{5}$ This context increases the risk 
of future infectious disease emergencies and decreasing access to ancestral pharmacopoeia, central to Indigenous Peoples' medical practices and a potential source of treatment for future re-emergence of infectious diseases across populations. ${ }^{6}$ Deforestation and forest fragmentation are driven by increased illegal timber, extractive economies and large-scale farming (especially African palm oil and coca leaf). These activities are cutting deeper into areas of the forest where there is no state presence or oversight, putting the lives and territorial sovereignty of Indigenous Peoples in risk, particularly those living in isolation, threatening their existence and right to isolation. Furthermore, deforestation and forest degradation leading to biodiversity loss threatens Indigenous Peoples' food security, putting their health and well-being at an urgent risk. ${ }^{7}$ Food insecurity impacts microbiota homoeostasis with a direct impact on immune system development and response and therefore the ability to fight any infection.

Second, public policy must be developed from and with indigenous groups, including both female and male knowledge and initiatives. It should respect the biogeographic structure, with an intercultural, gender, intergenerational and multisectoral approach, taking into account not only the socioeconomic, sociocultural and environmental impact of the pandemic but also the risk resulting from socioeconomic isolation during the state of emergency which is challenging the livelihoods food security, individual health and child development of Amazonian families.

Third, given the current state of disinformation and alarming cases of self-medication across the Peruvian population, ${ }^{8}$ driven by inaccessible access to healthcare facilities, an increase of prices for basic fever medication, such as paracetamol (and other medications to treat COVID-19 symptoms), and an overwhelming number of infection rate and fatalities, there is a need of clear locally based healthcare responses. It is essential to train members of indigenous communities on clinical aspects and preventive measures related to the new pandemic. ${ }^{9}$ To strengthen the implementation of prophylaxis strategies and avoid the risks of taking medications without prior medical examination it is important to understand and acknowledge the cultural and linguistic heterogeneity of Indigenous Peoples, coproducing acceptable relief measures. There is also a need and an opportunity to use access and knowledge about local biodiversity and remedies to conduct research on a potential treatment, given that the majority of pharmaceuticals has a biological origin.

Faced with the difficulties of accessing health services, an indigenous health task force emerged: the Matico (Scientific name: Buddleja globosa. English: Matico pepper. https://www.minagri.gob.pe/portal/download/pdf/sectoragrario/agricola/lineasdecultivosemer gentes/MATICO.pdf) command of Pucallpa. The Matico command is composed of volunteers from the Shipibo indigenous people, determined to use predominantly medicinal plants and therapies belonging to ancestral female healers, known as raomi, to provide personalised care to patients with mild symptoms who are unable to access health services. This grassroots initiative shows that local participation has empowered indigenous women to address health needs, especially when there is limited or no presence of health personnel in remote communities. ${ }^{10}$ Community participation in the context of COVID-19 also implies that prevention, care and management of deceased indigenous people will often be in people's own hands and foster intergenerational dialogue as young people recover their grandmother's healing knowledge. Here, the indigenous, and predominantly, female use of plants, has also enabled women to deal with the risks and consequences of an increase in domestic violence due to confinement conditions.

Local initiatives like the Matico have grown in other Amazonian cities, such as Sepáhua and Atalaya, always empowering women and older people's knowledge to provide culturally relevant emotional and medical support over the last 6 months. It has also enabled coordination to ensure access to rapid tests, vital oxygen tanks and medicines, where regional government services failed coordinated and sufficient response. The Matico command appeared in a time when trust in the national healthcare system for the most marginalised people had been shattered mostly as a result of negative past experiences of discrimination and precarity of the healthcare system. The Matico command is a grassroots response vis-a-vis the incapacity of the national and regional governments and shows the importance of community engagement in developing the response. While this has been visible in urban areas, it becomes even more apparent in marginalised urban and in rural settings. There is an urgent need for rethinking the Peruvian healthcare system as a more participatory, community-engaged system that responds to local realities in a culturally appropriate way.

Fourth, this goes along with the increase of impact on mental health on local communities due to loss of family members, economic and food insecurity and the feeling of abandonment by the Peruvian government in times of emergency. Mental health services are already scarce and underfinanced in urban areas, even worse in rural areas. Intercultural mental health services addressing current needs within a pandemic context are urgently needed. Importantly, these need to be developed and addressed together with the community actors and should avoid a top-down approach and a purely biomedical approach.

Fifth, public planning policies need timely data to launch quick response actions, instead of reactive actions, as it is happening widely. Official epidemiological criteria were unable to follow since there was poor access to confirmation diagnostic test or contact trace capabilities in correlation with remoteness of some communities. It was impossible to perform and complete cases evaluation with the governmental criteria. A syndromic case definition and a community surveillance would have been a better approach for the indigenous context. ${ }^{11}$ 
Sixth, in the absence of a universal and inclusive health system, ${ }^{12}$ during the national quarantine ordered since $16 \mathrm{March}$, many indigenous people tried to return to the Ucayali region and their communities where they would have been able to and improve their survival strategies and have more access to indigenous preventive and therapeutic practices. Unlike those returning from abroad, internally displaced people received poor, inhuman and humiliating treatment, giving rise to new infections and perpetuating the historic marginalisation of Indigenous People. ${ }^{13}$

Finally, we are aware of the state efforts ${ }^{14}$ but also of the limitations of public health services and insufficient state support. For indigenous communities and intercultural urban settlements, marginalisation, poverty and racism continue. There is an urgent need for solidarity and support with indigenous movements to respond to the pandemic and think and work beyond the current pandemic in the prevention of future pandemics through biodiversity conservation and inclusive indigenous public policy and sovereignty. This ought to be done in a safe, ethical way, to prevent vulnerable people from being infected by people without verification of their COVID-19 status. ${ }^{15}$ Indigenous Peoples will continue demanding their rights, proposing concrete measures to confront COVID-19 and raising their voices at the national and international levels to ensure the protection of their people.

\section{Author affiliations}

${ }^{1}$ Centre for Global Public Health, Queen Mary University of London, London, UK

${ }^{2}$ Centro de Investigaciones Tecnológicas, Biomédicas y Medioambientales - CITBM, Universidad Nacional Mayor de San Marcos, Lima, Peru

${ }^{3}$ Asociación Interétnica de Desarrollo de la Amazonia (AIDESEP), Lima, Peru

${ }^{4}$ ProPurus, Pucallpa, Peru

${ }^{5}$ Facultad de Salud Pública y Administración, Universidad Peruana Cayetano Heredia, Lima, Peru

${ }^{6}$ Vicepresidencia de Investigación, Universidad Nacional Intercultural de la Amazonia, Pucallpa, Peru

${ }^{7}$ Departamento Agroforestal Agrícola, Universidad Nacional Intercultural de la Amazonia, Pucallpa, Peru

${ }^{8}$ SHARE Amazónica, Pucallpa, Peru

${ }^{9}$ Department of World Languages and Cultures, Chapman University, Organge, California, USA

${ }^{10}$ Comité de Defensa del Agua, Iquitos, Loreto, Peru

${ }^{11}$ Red de Comunicadores Indígenas del Perú-Ucayali (REDCIP-U), Pucallpa, Peru

${ }^{12}$ Federación de Comunidades Nativas de Ucayali (FECONAU), Pucallpa, Peru

${ }^{13}$ Escuela de Sociologia, Facultad de Ciencias Sociales, Universidad Nacional Mayor de San Marcos, Lima, Peru

${ }^{14}$ Department of Anthropology, The London School of Economics and Political Science, London, UK

${ }^{15}$ Facultad de Ciencias del Ambiente, Universidad Nacional Santiago Antúnez de Mayolo, Huaraz, Peru

${ }^{16}$ Department of Anthropology, University of Massachusetts, Amherst,

Massachusetts, USA

${ }^{17}$ Research Group Neonatology, Department of Pediatrics, Faculty of Medicine, Universidad Nacional Mayor de San Marcos, Lima, Peru

${ }^{18}$ Department of Medicine, Neonatal Unit, Instituto Nacional de Salud del Niño, Lima, Peru

${ }^{19}$ Facultad de Salud Pública, Universidad Peruana Cayetano Heredia, Lima, Peru ${ }^{20}$ Instituto de Investigación, Universidad Católica de Los Ángeles de Chimbote, Chimbote, Peru
${ }^{21}$ CRONICAS Center of Excellence in Chronic Disease, Universidad Peruana Cayetano Heredia, Lima, Peru

${ }^{22}$ Dickinson College, Carlisle, Pennsylvania, USA

${ }^{23}$ Departamento de Medicina Preventica y Salud Pública, Facultad de Medicina,

Universidad Nacional Mayor de San Marcos, Lima, Peru

${ }^{24}$ Escuela Académico Profesional de Antropología, Universidad Nacional Mayor de San Marcos, Lima, Peru

Twitter Doreen Montag @drdmontag, José Sanchez-Choy @pucallpacity, Rodrigo Lazo @RodrigoLaz_0 and Elaine C. Flores @osahermosa2010

Acknowledgements The authors would like to thank Sergio Salomon Castillo for contributions to an earlier draft.

Contributors All authors have equally contributed to the commentary.

Funding DM and CAD were supported through Medical Research Council-MRC grant number MR/S024654/1 and by the Fondo Nacional de Desarrollo Científico, Tecnológico y de Innovación Tecnológica—FONDECYT, grant number 033-2019. CZC was supported by the National Institute for Health Research (NIHR) (using the UK's Official Development Assistance (ODA) Funding) and Wellcome Trust [218743/Z/19/Z] under the NIHR-Wellcome Trust Partnership for Global Health Research. The views expressed are those of the authors and not necessarily those of Wellcome Trus, the NIHR or the Department of Health and Social Care; and is member of the Indigenous Health and Adaptation to Climate Change Research Group. MAP was supported by a grant from the Swiss National Science Foundation [Grant IZ08Z0_177385].

Competing interests None declared.

Patient consent for publication Not required.

Provenance and peer review Not commissioned; internally peer reviewed.

Data availability statement There are no data in this work.

Open access This is an open access article distributed in accordance with the Creative Commons Attribution 4.0 Unported (CC BY 4.0) license, which permits others to copy, redistribute, remix, transform and build upon this work for any purpose, provided the original work is properly cited, a link to the licence is given, and indication of whether changes were made. See: https://creativecommons.org/ licenses/by/4.0/.

\section{ORCID iDs}

Doreen Montag http://orcid.org/0000-0003-1365-1913

Elaine C. Flores http://orcid.org/0000-0002-6195-9595

\section{REFERENCES}

11 Anderson I, Robson B, Connolly M, et al. Indigenous and tribal peoples' health (the Lancet-Lowitja Institute global collaboration): a population study. Lancet 2016;388:131-57.

2 Regional RI. Covid-19 en la Amazonía: Awajún y Kichwa son los pueblos indígenas más afectados; 2020.

3 Denuncia al Estado del Perú ante El Sistema Internacional de Protección de Los Derechos Humanos, 2020. Available: http:// www.aidesep.org.pe/sites/default/files/media/noticia/Denuncia\% 20AIDESEP\%20ante\%20la\%20\%20ONU.pdf [Accessed $20 \mathrm{Apr}$ 2020].

4 INd S. Dialogo Intercultural en Salud. Lima: Instituto Nacional de Salud, 2014.

5 Fd C, Lopes GR, Brondizio ES. The Brazilian Amazon in Times of COVID-19: from crisis to transformation? Ambiente \& Sociedade 2020;23.

6 Belaunde LE. Comando Matico en Pucallpa desafía la interculturalidad inerte del Estado. La Mula, 2020 [Accessed 9 Aug 2020].

7 Blundo-Canto G, Cruz-Garcia GS, Talsma EF, et al. Changes in food access by mestizo communities associated with deforestation and agrobiodiversity loss in Ucayali, Peruvian Amazon. Food Security 2020:1-22.

8 Fernández Calvo L. Automedicación en medio de la pandemia: Lo que no es recomendable en la lucha contra el coronavirus. El Comercio 2020.

9 Cardenas C. Promotores de salud, una alternativa para atender el COVID-19 en las comunidades indígenas. La Mula 2020.

10 Defensoria del Pueblo. Informe Defensorial 169. La defensa del derecho de los pueblos indígenas a una salud intercultural, 2015. 
Available: https://www.defensoria.gob.pe/wp-content/uploads/2018/ 05/Informe-Defensorial-N-169.pdf

11 Lazo-Landivar R. Subregistro y etnocidio en los pueblos indígenas. Ojo Público, 2020.

12 RPP. La pandemia del COVID-19 puede impulsar a mejorar nuestro sistema de salud 2020.

13 Redacción El Comercio. Perú, India y otros países donde personas se movilizan a pie rumbo a otras ciudades por el coronavirus. EI Comercio 2020.
14 Ministerio de Salud. Minsa destina más de S/ 88 millones para prevención y atención de casos Covid-19 en comunidades amazónicas [press release], 2020. Available: https://www.gob. pe/institucion/minsa/noticias/165811-minsa-destina-mas-de-s88-millones-para-prevencion-y-atencion-de-casos-covid-19-encomunidades-amazonicas [Accessed 27 May 2020].

15 Persad G, Emanuel EJ. The Ethics of COVID-19 Immunity-Based Licenses ("Immunity Passports"). JAMA 2020;323:2241-2. 